\title{
BMJ Open Overweight and its associated risk factors among urban school adolescents in Nepal: a cross-sectional study
}

\author{
Suneel Piryani, ${ }^{1}$ Kedar Prasad Baral, ${ }^{2}$ Bandana Pradhan, ${ }^{1}$ Amod Kumar Poudyal, ${ }^{1}$ \\ Rano Mal Piryani ${ }^{3}$
}

To cite: Piryani S, Baral KP, Pradhan B, et al. Overweight and its associated risk factors among urban school adolescents in Nepal: a cross-sectional study. BMJ Open 2016;6: 010335 . doi:10.1136/bmjopen-2015010335

- Prepublication history and additional material is available. To view please visit the journal (http://dx.doi.org/ 10.1136/bmjopen-2015010335).

Received 22 October 2015 Revised 29 March 2016 Accepted 29 April 2016

CrossMark

For numbered affiliations see end of article.

Correspondence to Dr Suneel Piryani; suneel.piryani@gmail.com

\section{ABSTRACT}

Objectives: The prevalence of non-communicable diseases is increasing in Nepal. Overweight and obesity are the major risk factors of many non-communicable diseases. Adolescence is a critical phase for development of overweight and obesity. Risk factors associated with overweight and obesity are not well understood in Nepal. The objective of the study was to identify the factors associated with overweight and obesity among adolescent students.

Setting: A cross-sectional descriptive study was carried out on higher secondary school students in the Lalitpur sub-metropolitan city, Nepal.

Participants: A random sample of 360 students aged 16-19 years from eight schools was included in the study.

Results: The prevalence of overweight among adolescent students was $12.2 \%$ (95\% Cl 8.9 to 15.5). Factors associated with being overweight included being male (adjusted OR (AOR) 2.64, 95\% Cl 1.18 to 4.88), studying in private school (AOR 2.10, 95\% Cl 1.03 to 4.28 ), high socioeconomic status family (AOR 4.77 , $95 \% \mathrm{Cl} 1.36$ to 16.72 ), watching television for more than $2 \mathrm{~h}$ per day (AOR 8.86, 95\% CI 3.90 to 20.11), and consuming fruit four times or less per week (AOR 3.13, $95 \% \mathrm{Cl} 1.39$ to 7.01 ). There was no statistically significant association between adolescent overweight and age, ethnicity, mother's education level, mother's occupation, number of siblings or family type.

Conclusions: Socioeconomic status, watching television for a longer time and consuming less fruit are major risk factors for overweight among adolescents in Nepal. Interventions are needed to increase awareness about the risk factors of adolescent overweight and obesity to decrease prevalence of overweight-associated non-communicable diseases.

\section{INTRODUCTION}

Today overweight and obesity contribute to the major public health problems worldwide. Although once considered a major problem in only affluent countries, overweight and obesity are now on the rise even in low- and middle-income nations such as Nepal. ${ }^{1}$ This

\section{Strengths and limitations of this study}

- This study is one of only a few conducted in Nepal that have analysed risk factors associated with overweight among urban adolescent students.

- Schools and participants of the study were selected randomly, which increases the strength of the study.

- This study was conducted in eight schools in Lalitpur sub-metropolitan city. So the risk factors identified may not be representative of every urban city in Nepal.

- The study findings are based on self-reporting by the students, and such findings are likely to suffer from over- or under-reporting and recall bias.

- The cross-sectional nature of the study limits drawing of inferences about causation.

may be due to ongoing urbanisation and economic transitions (subsistence to market) in Nepal. Nepal is urbanising at a fast pace, its urban population increasing to $17 \%$ of the total population in 2011 from $13.9 \%$ in 2001. ${ }^{2}$ The urban population growth rate is $3.38 \%$, whereas rural and total population growth rates were $1.03 \%$ and $1.4 \%$, respectively, in 2011. ${ }^{2}$ Economic transition and the urbanisation process precipitate increased levels of lifestyle-related risk factors such as low physical activity and changes in dietary habits. ${ }^{3}$ The prevalence and risk of overweight and obesity during childhood and adolescence are increasing at a greater pace in developing nations than in developed ones. ${ }^{1}$ Overweight and obesity are the major risk factors for non-communicable diseases (NCDs) such as diabetes, osteoarthritis and cardiovascular diseases. WHO estimates that NCDs cause $68 \%$ of deaths globally, and nearly three-quarters of all NCD deaths occur in low- and middle-income countries. ${ }^{4}$

Adolescence is a critical phase for the development of obesity because of various 
biological, psychological, social and environmental changes. ${ }^{5} 6$ Adolescence overweight and obesity may persist into adulthood. A prospective longitudinal study showed that the $56 \%$ of male subjects and $42 \%$ of female subjects who were overweight in adolescence remained overweight in adulthood, and the $47 \%$ of male subjects and $55 \%$ of female subjects who were obese in adolescence remained obese in adulthood. ${ }^{7}$ Adolescence overweight and obesity may increase the risk of developing NCDs at a younger age and consequently a premature death. In addition to future health risks, overweight and obese adolescents also suffer shortterm health consequences. ${ }^{1}$ In addition, their participation in school and other daily activities is also limited depending on the degree of obesity.

In Nepal, nearly a quarter of the population (24\%) are adolescents. ${ }^{8}$ NCDs account for $60 \%$ of all deaths in Nepal, and $23 \%$ are caused by cardiovascular diseases. ${ }^{9}$ A national survey conducted in Nepal in 2013 reported the prevalence of overweight among Nepalese people (15-69 years age) to be $17.7 \%{ }^{10}$ Research on the prevalence and factors associated with overweight among Nepalese adolescents has so far been limited. ${ }^{11}$ This study is an attempt to fill the information and knowledge gap in this area, and the potential use of this information will be in designing policy and programmes to appropriately address this problem in a timely manner.

\section{METHODS}

\section{Study area}

This study was conducted in Lalitpur sub-metropolitan city, one of the major cities in Nepal. It is adjacent to the capital city of Kathmandu and is located in the southeast part of Kathmandu valley. It is a fast growing area and has the highest density of schools in the Kathmandu valley.

\section{Study design and selection of participants}

A cross-sectional study was conducted during October to November 2014. A multistage random sampling method was used to select the participants. The study area Lalitpur sub-metropolitan city was purposively selected. A list of higher secondary schools affiliated to the Higher Secondary Education Board (HSEB) of Nepal was downloaded from the HSEB website. There were 52 schools in the sampling frame (13 government and 39 private) in this study. Two separate lists of private and government schools were prepared. Out of 52 schools, eight (four government and four private) were randomly chosen through a lottery method, and from each selected school one of grades 11 or 12 was randomly selected. All students of the selected grade were included in the study. A total of 381 students filled out the self-administered questionnaire, and 21 questionnaires were discarded during data analysis (eight questionnaires were incompletely filled in, 11 students were over 19 years of age, and two physically disabled students did not provide informed consent for measuring their weight). Responses and anthropometric measurements for 360 students were included in the study.

\section{Data collection and statistical analysis}

Data were collected using a self-administered, pretested and structured questionnaire. Anthropometric measurements (height and weight) were obtained as per WHO guidelines using a SECA digital weighing scale and stadiometer. ${ }^{12}$ The accuracy of the weighing scale and stadiometer were checked using the standard weight and height at the beginning of every data collection session and after measurement of every five students. Data were entered in Epi-data V.3.1. Anthropometric calculation was conducted using WHO Anthro Plus software V.1.0.4. ${ }^{13}$ Statistical analysis was performed using SPSS V.21. Bivariate and multivariate binary logistic regression analyses were conducted to determine the association between dependent (overweight) and independent (risk factors) variables. Initially, in bivariate analysis, a single variable at a time was entered; unadjusted OR and $95 \%$ CI were computed for all independent variables. Multicollinearity was checked among the variables, and there was no significant collinearity (variance inflation factor 1-2). Multivariate analysis with all independent variables entered at the same time was completed to adjust for the effect of confounding, and adjusted OR and $95 \%$ CI were computed. The Hosmer-Lemeshow test was performed to test the goodness-of-fit of the multivariate logistic regression model, and the model was found to be a good fit $(p>0.05)$.

\section{Variables}

Adolescents whose body mass index (BMI) for age was above $+1 \mathrm{SD}$ from the median of the WHO reference population were classified as overweight. ${ }^{14}$ Age was calculated by subtracting the date of birth, given by the students, from the date of data collection. Ethnicities of students were organised into an advantaged group (including advantaged Janajatis and upper caste) and a relatively disadvantaged group (including Dalits, disadvantaged Janajatis, disadvantaged non-dalit Terai people and religious minorities). Socioeconomic status was computed by wealth index using principal component analysis, considering the asset holdings of the participants. Tertiles were generated data and organised into low (poor), middle and high (rich) categories. The components included in the wealth index were ownership of a house, vehicles, animals, electronic goods (refrigerator, radio, TV, computer, fan), furniture (sofa, bed, cupboard, table, chair), mobile phone and telephone, housing characteristics, and type of fuel used for cooking. Fruit consumption by the students during the past week was grouped as four or less servings a week and more than four servings a week. Similarly, the average number of hours of television watched was grouped as $2 \mathrm{~h}$ or less per day and more than $2 \mathrm{~h}$ per day. 


\section{Questionnaire}

A structured questionnaire was developed based on study objectives. For wealth index, a validated Nepal Demographic and Health Survey 2011 (NDHS) questionnaire measure was adapted. ${ }^{15}$ For fruit consumption, a list of locally available (market and locally grown) fruits in the study season was developed, and students were asked to tick number of times they had consumed each particular fruit during the past week. Students were asked to tick the average number of hours per day they watched television during the past week. A pilot study of the questionnaire was performed in one non-sampled school. The questionnaire (consisting of sociodemographics, watching television and fruit consumption) was administered to 20 students. The questionnaires were found to be appropriate (see online supplementary file).

\section{Ethics consideration}

The study was approved by the institutional review board of the Institute of Medicine, Tribhuvan University, Kathmandu, Nepal. Informed written consent was obtained from the sampled school authorities and participants. Confidentiality of information was assured and ensured throughout the study. Information on causes, health consequences, and prevention of nutritional problems such as underweight, overweight and micronutrient deficiency was given to the students.

\section{RESULTS}

The prevalence of overweight was $12.2 \%$ (95\% CI 8.9 to 15.5). Table 1 shows the general characteristics of adolescent student participants. The mean age, weight, height and BMI of the participants were 16.98 years (range $16.88-17.08), \quad 52.5 \mathrm{~kg}$ (range 51.5-53.5), $159.9 \mathrm{~cm}$ (range 159.0-160.8) and $20.5 \mathrm{~kg} / \mathrm{m}^{2}$ (range 20.2-20.8) respectively. Bivariate analysis showed that six factors were independently associated with overweight in adolescents (table 2). In multivariate analysis, being male, studying in a private school, having a high socioeconomic status, watching television more than $2 \mathrm{~h}$ per day, and consuming fruit four times or less a week were significantly statistically associated with overweight. However, age, ethnicity, mother's educational level, mother's occupation, family type and number of siblings did not show a statistically significant association with being overweight (table 2). Separate analyses in male and female subjects were performed (see online supplementary tables S1 and S2). In male subjects, school type, socioeconomic status, watching television more than $2 \mathrm{~h}$ per day and consuming fruit four times or less a week showed a statistically significant association with being overweight. In female subjects, socioeconomic status, watching TV more than $2 \mathrm{~h}$ per day and consuming fruit four times or less a week showed a statistically significant association with being overweight.

Male students were 2.64 times more likely to be overweight than female students (adjusted OR (AOR) 2.64,
Table 1 General characteristics of sampled adolescent students

\begin{tabular}{|c|c|c|}
\hline Characteristic & Frequency & Percentage \\
\hline \multicolumn{3}{|l|}{$\mathrm{Age}^{*}$} \\
\hline $16-17$ years & 268 & 74.4 \\
\hline $18-19$ years & 92 & 25.6 \\
\hline \multicolumn{3}{|l|}{ Sex } \\
\hline Female & 190 & 52.8 \\
\hline Male & 170 & 47.2 \\
\hline \multicolumn{3}{|l|}{ Ethnicity } \\
\hline Advantaged & 235 & 65.3 \\
\hline Relatively disadvantaged & 125 & 34.7 \\
\hline \multicolumn{3}{|l|}{ School type } \\
\hline Private & 180 & 50 \\
\hline Government & 180 & 50 \\
\hline \multicolumn{3}{|l|}{ Mother's educational level } \\
\hline Formal education & 226 & 62.8 \\
\hline No formal education & 134 & 37.2 \\
\hline \multicolumn{3}{|l|}{ Mother's occupation } \\
\hline $\begin{array}{l}\text { Working outside home also/ } \\
\text { employed/non-housewife }\end{array}$ & 185 & 51.4 \\
\hline Unemployed/housewife & 175 & 48.6 \\
\hline \multicolumn{3}{|l|}{ Family type } \\
\hline Nuclear & 244 & 67.8 \\
\hline Extended/joint & 116 & 32.2 \\
\hline \multicolumn{3}{|l|}{ No of siblings } \\
\hline Up to 2 & 264 & 73.3 \\
\hline More than 2 & 96 & 26.7 \\
\hline \multicolumn{3}{|l|}{ Socioeconomic status $†$} \\
\hline Rich & 120 & 33.3 \\
\hline Middle class & 120 & 33.3 \\
\hline Poor & 120 & 33.3 \\
\hline \multicolumn{3}{|l|}{ Watching TV } \\
\hline$\leq 2 \mathrm{~h} /$ day & 281 & 78.1 \\
\hline$>2$ h/day & 79 & 21.9 \\
\hline \multicolumn{3}{|l|}{ Fruit consumption } \\
\hline$\leq 4$ times/week & 184 & 51.1 \\
\hline$>4$ times/week & 176 & 48.9 \\
\hline \multicolumn{3}{|c|}{$\begin{array}{l}\text { *Mean } \pm \text { SD age } 16.98 \pm 0.98 \text { years. } \\
\text { tWealth index was computed using principal component analysis; } \\
\text { the components included were ownership of house, vehicles, } \\
\text { animals, electronic goods (refrigerator, radio, TV, computer, fan), } \\
\text { furniture (sofa, bed, cupboard, table, chair), mobile phone and } \\
\text { telephone, housing characteristics, and type of fuel used for } \\
\text { cooking. }\end{array}$} \\
\hline
\end{tabular}

95\% CI 1.18 to 4.88$)$. Likewise, students studying in private schools were 2.1 times more likely to be overweight than students studying in government schools (AOR 2.10, 95\% CI 1.03 to 4.28). Similarly, students from rich families were 4.77 times more likely to be overweight than students from poor families (AOR 4.77, $95 \%$ CI 1.36 to 16.72 ). Students who spent more than $2 \mathrm{~h}$ per day watching television were 8.86 times more likely to be overweight than students who spent less than $2 \mathrm{~h}$ per day watching television (AOR 8.86, 95\% CI 3.90 to 20.11). Students who consumed fruit four times or less a week were 3.13 times more likely to be overweight than students who consumed fruit more than four times a week (AOR 3.13, 95\% CI 1.39 to 7.01 ) (table 2). 
Table 2 Risk factors for overweight among adolescent students in Nepal

\begin{tabular}{|c|c|c|c|c|c|c|}
\hline Characteristic & $\begin{array}{l}\begin{array}{l}\text { Overweight } \\
(n=44)\end{array} \\
\text { No (\%) }\end{array}$ & 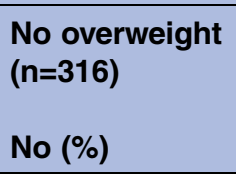 & $\begin{array}{l}\text { Unadjusted OR } \\
(95 \% \mathrm{Cl})\end{array}$ & p Value & $\begin{array}{l}\text { Adjusted OR } \\
(95 \% \mathrm{Cl})\end{array}$ & p Value \\
\hline \multicolumn{7}{|l|}{$\overline{\text { Age }}$} \\
\hline $16-17$ years & $35(13.1)$ & 233 (86.9) & $\begin{array}{l}1.38 \\
(0.64 \text { to } 3.00)\end{array}$ & 0.409 & $\begin{array}{l}1.05 \\
(0.37 \text { to } 2.94)\end{array}$ & 0.927 \\
\hline $18-19$ years & $9(9.8)$ & $83(90.2)$ & 1 & & 1 & \\
\hline \multicolumn{7}{|l|}{ Sex } \\
\hline Male & 27 (15.9) & $143(84.1)$ & $\begin{array}{l}1.92 \\
(1.00 \text { to } 3.67)\end{array}$ & $0.048^{*}$ & $\begin{array}{l}2.64 \\
(1.18 \text { to } 4.88)\end{array}$ & $0.018^{*}$ \\
\hline Female & $17(8.9)$ & $173(91.1)$ & 1 & & 1 & \\
\hline \multicolumn{7}{|l|}{ Ethnicity } \\
\hline Advantaged & $32(13.6)$ & $203(86.4)$ & $\begin{array}{l}1.48 \\
(0.74 \text { to } 3.00)\end{array}$ & 0.271 & $\begin{array}{l}1.38 \\
(0.57 \text { to } 3.31)\end{array}$ & 0.476 \\
\hline \multirow{2}{*}{\multicolumn{7}{|c|}{ School type }} \\
\hline & & & & & & \\
\hline Private & $29(16.1)$ & $151(83.9)$ & $\begin{array}{l}2.11 \\
(1.09 \text { to } 4.09)\end{array}$ & $0.027^{*}$ & $\begin{array}{l}2.10 \\
\text { (1.03 to } 4.28)\end{array}$ & $0.042^{*}$ \\
\hline Government & $15(8.3)$ & $165(91.7)$ & 1 & & 1 & \\
\hline \multicolumn{7}{|l|}{ Mother's educational level } \\
\hline Formal education & $32(14.2)$ & $194(85.8)$ & $\begin{array}{l}1.67 \\
(0.30 \text { to } 1.20)\end{array}$ & 0.148 & $\begin{array}{l}0.85 \\
(0.32 \text { to } 2.22)\end{array}$ & 0.732 \\
\hline No formal education & $12(9.0)$ & $122(91.0)$ & 1 & & 1 & \\
\hline \multicolumn{7}{|l|}{ Mother's occupation } \\
\hline $\begin{array}{l}\text { Working outside home also/ } \\
\text { employed/non-housewife }\end{array}$ & $27(14.6)$ & $158(85.4)$ & $\begin{array}{l}1.59 \\
(0.83 \text { to } 3.03)\end{array}$ & 0.673 & $\begin{array}{l}1.18 \\
(0.54 \text { to } 2.60)\end{array}$ & 0.673 \\
\hline Unemployed/housewife & $17(9.7)$ & $158(90.3)$ & 1 & & 1 & \\
\hline \multicolumn{7}{|l|}{ Family type } \\
\hline Nuclear & 34 (13.9) & $210(86.1)$ & $\begin{array}{l}1.72 \\
(0.82 \text { to } 3.61)\end{array}$ & 0.154 & $\begin{array}{l}1.41 \\
(0.59 \text { to } 3.39)\end{array}$ & 0.445 \\
\hline Extended/joint & $10(8.6)$ & $106(91.4)$ & 1 & & 1 & \\
\hline \multicolumn{7}{|l|}{ No of siblings } \\
\hline Up to 2 & $39(14.8)$ & 225 (85.2) & $\begin{array}{l}3.15 \\
(1.20 \text { to } 8.26)\end{array}$ & $0.019^{*}$ & $\begin{array}{l}1.85 \\
\text { (0.61 to } 5.61)\end{array}$ & 0.097 \\
\hline More than 2 & $5(5.2)$ & $91(94.8)$ & 1 & & 1 & \\
\hline \multicolumn{7}{|l|}{ Socioeconomic status } \\
\hline High (rich) & $28(23.3)$ & $92(76.7)$ & $\begin{array}{l}4.26 \\
(1.85 \text { to } 9.80)\end{array}$ & $<0.001^{*}$ & $\begin{array}{l}4.77 \\
(1.36 \text { to } 16.72)\end{array}$ & $0.018^{*}$ \\
\hline Middle & $8(6.7)$ & $112(93.3)$ & $\begin{array}{l}1.00 \\
(0.36 \text { to } 2.76)\end{array}$ & 1.00 & $\begin{array}{l}0.93 \\
(0.27 \text { to } 3.18)\end{array}$ & 0.912 \\
\hline Low (poor) & $8(6.7)$ & $112(93.3)$ & 1 & & 1 & \\
\hline \multicolumn{7}{|l|}{ Watching TV } \\
\hline$>2$ h/day & 26 (32.9) & $53(67.1)$ & $\begin{array}{l}7.17 \\
\text { (3.67 to } 14.00)\end{array}$ & $<0.001^{*}$ & $\begin{array}{l}8.86 \\
(3.90 \text { to } 20.11)\end{array}$ & $<0.001^{*}$ \\
\hline$\leq 2 \mathrm{~h} /$ day & $18(6.4)$ & $263(93.6)$ & 1 & & 1 & \\
\hline \multicolumn{7}{|l|}{ Fruit consumption } \\
\hline$\leq 4$ times/week & $31(16.8)$ & $153(83.2)$ & $\begin{array}{l}2.54 \\
(1.28 \text { to } 5.04)\end{array}$ & $0.008^{*}$ & $\begin{array}{l}3.13 \\
(1.39 \text { to } 7.01)\end{array}$ & $0.006^{*}$ \\
\hline$>4$ times/week & $13(7.4)$ & $163(92.6)$ & 1 & & 1 & \\
\hline
\end{tabular}

\section{DISCUSSION}

The study data suggest that being male, studying in a private school, belonging to a family with high socioeconomic status, watching television for more than $2 \mathrm{~h}$ per day, and consuming fruit four times or less a week were potential risk factors for overweight among
Nepalese adolescent students. In this study, prevalence of overweight among adolescents in Nepal was found to be $12.2 \%$, which is lower than that reported by studies from Pakistan, India and China. ${ }^{16-19}$ However, it is higher than results from a study conducted in the Kaski district of Nepal. ${ }^{11}$ The male students were nearly three 
times more likely to be overweight than the female students. This finding is consistent with the studies from Pakistan, India and China, which reported higher prevalence in male than female subjects. ${ }^{16-23}$

The present study showed that adolescents studying in private schools were twice as likely to be overweight than those studying in government schools. The finding is consistent with studies conducted in India. ${ }^{18}{ }^{21}$ In our study, overweight among adolescents was found to be significantly associated with socioeconomic status. The students from higher socioeconomic backgrounds were nearly five times more likely to be overweight than students from poor families. This finding is compatible with studies carried out in India. ${ }^{17} 20-2224$ Students from families with higher socioeconomic background have more purchasing power for calorie-dense and nutrient-poor fast foods.

Students who spent more than $2 \mathrm{~h}$ a day watching television were found to be nearly nine times more likely to be overweight than those who spent less than $2 \mathrm{~h}$ a day watching television. Watching television could be contributing to the increased incidence of overweight among adolescents in many ways including: (a) the increase in sedentary behaviour and decrease in physical activity; (b) increased snacking while watching television; (c) disturbance of normal sleeping pattern caused by watching television; and (d) increasing trends towards unhealthy eating patterns influenced by advertisements of junk/fast foods. ${ }^{6}{ }^{25-27}$ A study conducted in Nepal showed that a quarter of advertisements that appeared on selected Nepali and Indian television channels were related to junk foods and most of these advertisements were targeted at children. ${ }^{28}$ A study conducted on adolescent girls in Sri Lanka showed that risk of overweight was three times higher among those who had a screen time of more than $2 \mathrm{~h}$ a day. ${ }^{29}$ Another study carried out in India on adolescents reported the risk of overweight was seven times higher among those who had screen time of more than $4 \mathrm{~h}$ a day. ${ }^{24}$

Fruit and vegetables are an important part of a healthy diet; their adequate daily consumption can help weight loss and prevent many NCDs. ${ }^{30}$ In the present study, students who consumed fruit four times or less a week were three times more likely to be overweight than students who consumed fruit more than four times per week. A study on Pakistani adolescents showed the same association, with students who consumed fruit four or more times a week being less likely to be obese than those who consumed fruit less than four times a week. ${ }^{16}$ Another study conducted on adolescent girls in Sri Lanka showed that risk of overweight was twice as high among those who consumed fruit on fewer than 4 days a week. ${ }^{29}$

\section{Conclusion}

This study provides evidence of the high prevalence of overweight among adolescents living in one urban area of Nepal. Socioeconomic status, watching television for long periods of time, and consuming less fruit are major risk factors for overweight among adolescents in Nepal.
Policies and programmes not only from the Ministry of Health and Population but also from the Ministry of Education and Ministry of Youth and Sports are needed to address this fast growing problem appropriately and in a timely manner. An enabling environment is of paramount importance to increase awareness about the risk factors for overweight in adolescence to decrease the prevalence of overweight-associated NCDs in the upcoming generations of Nepal.

\section{Author affiliations}

${ }^{1}$ Department of Community Medicine and Public Health, Institute of Medicine, Tribhuvan University, Kathmandu, Nepal

${ }^{2}$ Department of Community Health Sciences, Patan Academy of Health Sciences, Lalitpur, Nepal

${ }^{3}$ Department of Internal Medicine, Chitwan Medical College, Bharatpur, Chitwan, Nepal

Acknowledgements We acknowledge Mr Anurag Marasini, Mr Bimash Babu Shrestha and Ms Ranjana Jha for their help in data collection. We would to like to thank all school authorities and students who participated in the study.

Contributors SP was involved in conceptualising the study, reviewing the literature, designing the protocol, developing the questionnaire, data collection and analysis, and preparing the manuscript. AKP was involved in statistical analysis, interpretation of data and critically reviewing the manuscript. KPB, $\mathrm{BP}$ and RMP helped in conceptualising the study and critically reviewed the manuscript. All authors read and approved the final manuscript.

Funding This research received no specific grant from any funding agency in the public, commercial or not-for-profit sectors.

Competing interests None declared.

Ethics approval Institutional Review Board, Institute of Medicine, Tribhuvan University.

Provenance and peer review Not commissioned; externally peer reviewed.

Data sharing statement No additional data are available.

Open Access This is an Open Access article distributed in accordance with the Creative Commons Attribution Non Commercial (CC BY-NC 4.0) license, which permits others to distribute, remix, adapt, build upon this work noncommercially, and license their derivative works on different terms, provided the original work is properly cited and the use is non-commercial. See: http:// creativecommons.org/licenses/by-nc/4.0/

\section{REFERENCES}

1. World Health Organization. Obesity and overweight Fact sheet January 2015. http://www.who.int/mediacentre/factsheets/fs311/en/

2. Central Bureau of Statistics. Preliminary result of census 2011. Kathmandu: National Planning Commission, 2011.

3. World Health Organization. Obesity: preventing and managing the global epidemic: report of a WHO consultation on obesity. Geneva, 3-5 June 1997. 1998.

4. Mendis S. Global status report on noncommunicable diseases 2014. World Health Organization, 2014.

5. Dietz WH. Critical periods in childhood for the development of obesity. Am J Clin Nutr 1994;59:955-9.

6. Story M, Neumark-Sztainer D, French S. Individual and environmental influences on adolescent eating behaviors. J Am Diet Assoc 2002;102:S40-51.

7. Laitinen J, Power C, Järvelin M-R. Family social class, maternal body mass index, childhood body mass index, and age at menarche as predictors of adult obesity. Am J Clin Nutr 2001;74:287-94.

8. Ministry of Health and Population GoN. Nepal population report 2011. Kathmandu, 2011.

9. World Health Organization. Noncommunicable Diseases (NCD) Country Profiles, 2014. http://www.who.int/nmh/countries/npl_en.pdf

10. Aryal KK, Neupane S, Mehata S, et al. Non communicable diseases risk factors: STEPS Survey Nepal 2013. Kathmandu: Nepal Health Research Council, 2014. 
11. Acharya B, Chauhan HS, Thapa SB, et al. Prevalence and socio-demographic factors associated with overweight and obesity among adolescents in Kaski district, Nepal. Indian J Community Health 2014;26:118-22.

12. World Health O. Physical status: the use and interpretation of anthropometry, Report of a WHO Expert Committee. 1995.

13. WHO WHO AnthroPlus for Personal Computers Manual: Software for Assessing Growth of the World's Children and Adolescents. Geneva: WHO, 2009.

14. WHO Growth References 2007: Geneva: WHO.: http://www.who.int/ growthref/en/.

15. Ministry of Health and Population (MOHP) [Nepal] NE, and ICF International Inc. Nepal demographic and health survey 2011. Kathmandu, Nepal, 2012.

16. Ahmed J, Laghari A, Naseer M, et al. Prevalence of and factors associated with obesity among Pakistani schoolchildren: a school-based, cross-sectional study. East Mediterr Health $J$ 2013;19:242-7.

17. Chhatwal J, Verma M, Riar SK. Obesity among pre-adolescent and adolescents of a developing country (India). Asia Pac J Clin Nutr 2003;13:231-5.

18. Gupta DK, Shah P, Misra A, et al. Secular trends in prevalence of overweight and obesity from 2006 to 2009 in urban Asian Indian adolescents aged 14-17 years. PLOS ONE 2011;6: e17221.

19. Guo X, Zheng L, Li Y, et al. Prevalence and risk factors of being overweight or obese among children and adolescents in northeast China. Pediatr Res 2013;74:443-9.

20. Ramachandran A, Snehalatha C, Vinitha R, et al. Prevalence of overweight in urban Indian adolescent school children. Diabetes Res Clin Pract 2002:57:185-90.
21. Kaur S, Sachdev H, Dwivedi S,et al. Prevalence of overweight and obesity amongst school children in Delhi. Asia Pac J Clin Nutr 2008;17:592-6.

22. Cherian AT, Cherian SS, Subbiah S. Prevalence of obesity and overweight in urban school children in Kerala, India. Indian Pediatr 2012;49:475-7

23. Goyal RK, Shah VN, Saboo BD, et al. Prevalence of overweight and obesity in Indian adolescent school going children: its relationship with socioeconomic status and associated lifestyle factors. J Assoc Physicians India 2010;58:151-8.

24. Kotian MS, Kumar G, Kotian SS. Prevalence and determinants of overweight and obesity among adolescent school children of South Karnataka, India. Indian J Community Med 2010;35:176.

25. Jordan AB, Kramer-Golinkoff EK, Strasburger VC. Does adolescent media use cause obesity and eating disorders? Adolesc Med 2008;19:431-49.

26. Marshall SJ, Biddle SJ, Gorely T, et al. Relationships between media use, body fatness and physical activity in children and youth: a meta-analysis. Int $J$ Obes Relat Metab Disord 2004;28:1238-46.

27. Mulligan DA. Policy Statement: Children, Adolescents, Obesity, and the Media. Pediatrics 2011;128:594.

28. Rapid Assessment on Media Coverage of Junk Food and its Content Analysis on Selected Nepali and Indian Television Channels. Kathmandu, Nepal: Resource Centre for Primary Health Care (RECPHEC), Kathmandu, 2014.

29. Rathnayake KM, Roopasingam T, Wickramasighe VP. Nutritional and behavioral determinants of adolescent obesity: a case-control study in Sri Lanka. BMC Public Health 2014;14:1291.

30. Tohill BC. Dietary intake of fruit and vegetables and management of body weight. WHO, 2005. 